\title{
Decision Support Systems Selection of Soang Superior Brood Using Weighted Product (WP) and Simple Additive Weighting (SAW) Method
}

\author{
Ramadiani $^{1 *}$, Reynaldi Kurniawan ${ }^{1}$, Awang Harsa Kridalaksana $^{1}$ and Muhammad Labib Jundillah ${ }^{2}$ \\ ${ }^{1}$ Faculty of Computer Science and Information Technology, Mulawarman University, Samarinda - Indonesia \\ ${ }^{2}$ Magister Program of Information System, School of Post Graduate Studies, Diponegoro University, Semarang, Indonesia
}

\begin{abstract}
Gurame Soang Latin name Osphronomus Labirynthici gouramy including fish, that as the fish have gills and breathing apparatus in the form of additional gills (Labyrinth). One important factor in fish farming Soang Gurame is holding elections. Superior brood has characteristics identical, to distinguish it needs to experience since it is quite difficult. Some of the assessment factors in selecting a superior brood that could be considered in the cultivation of the fish farmers Gurame Soang as ideal weight, physical disability, movement of fish, the shape of the head, and the body color. All of these factors combined to get an assessment that could help the decision making process fish Gurame Soang superior sires. This study used two methods that have selected the calculation accuracy of the decision-making process. The method used is the Weighted Product and Simple Additive weighting. The results of the research that has been done, it can be concluded the total number of alternative Gurame Soang superior sires data as many as 10 fish, and obtained the results of testing the level of accuracy by using the results of data from a breeder Gurame Soang superior sires, Method of Weighted Product got an accuracy of $80 \%$ and methods Simple Additive weighting got an accuracy of $60 \%$.
\end{abstract}

Keywords: Gurame Soang; Decision Support Systems; Weighted Product (WP); Simple Additive Weighting (SAW).

\section{Introduction}

Gurame is a fish native waters of Indonesia which has the Latin name Osphronomus Labirynthici gouramy including fish, that as the fish have gills and breathing apparatus in the form of additional gills (Labyrinth). Labyrinth is a respirator in the form of additional membrane-shaped protrusions on the top edge of the main gill layer. Gurame can grow in tropical or subtropical waters. These fishes are geographically scattered in various countries, such as Indonesia (Sumatra, Java, Madura, Kalimantan and Sulawesi). Carp populous 8 types, namely Gurame Soang, Giant Gourami, Japanese carp, Bastar Gurame, Gurame Cotton, Paris Bluesafir Gurame, Gurame Stone, Porcelain Gurame. Gourami is an important aquaculture commodity in Indonesia. Giant gourami grows at a relatively slow rate, which can hinder efforts to increase gourami production to meet high market demand [1-2].

Gurame Soang is the most popular type of carp. In addition to his name often mentioned in public, Gurame Soang is also the most widely cultivated. The characteristics of the most obvious is the forehead bulging and his shaped flat, has a body color combination of white and black, and the tail is reddish color that is only visible when they were children with ages around before one year, Growth of this carp can weigh $8 \mathrm{~kg}$ and can be up to $65 \mathrm{~cm}$ long. For carp species including the size of a large carp can even say that most big carp species and productive [1-2].

An important factor in fish farming Soang Gurame is holding elections. Superior sires have identical characteristics, but to distinguish it needs experience because it is quite difficult. Some of the assessment factors in selecting superior sires. That could be considered in the cultivation of the fish farmers Gurame Soang as ideal weight, physical disability, movement of fish, the shape of the head, and body color. Then it would be helpful if available a system that can provide decision support for farmers' novice carp. All of these factors combined to get an assessment that could help the decision making process fish Gurame Soang superior sires [1].

Decision process urgently need the right method that can be used especially for cases such as the selection of superior sires this Gurame fish. However, this study will use two methods that will select the best method based on the calculation accuracy of the decision-making process. The method to be used is the method Simple Additive Weighting (SAW) by the method of Weighted Product (WP).

* Corresponding author: ilkom.ramadiani@gmail.com 


\section{Literature Review}

\subsection{Decision Support System}

Decision support system is a computer-based system that produces a variety of alternative decisions to assist management in dealing with various problems in a structured or unstructured using data and models. To produce a good decision in the decision support system, needs to be supported by quality information and facts, among others: completeness, accuracy, punctuality, clarity, and flexibility. This attribute is related to the degree of adaptation of the information produced to the needs of the various decisions to be taken and against a different group of decision makers [3-8].

\subsection{Gurame Soang}

Soang Gurame name is derived from a similar head shape swan which had a prominent forehead both male and female. The carp is most prevalent in West Java. Therefore, many argue about the origin of species of carp in this area of West Java. The characteristics of the most obvious are the forehead prominent and characteristics of others is a form of body flat aft, has a color grow a combination of white and black, and the tail is a reddish color that is only visible when they were children with ages around before one year [1-2].

The growth of this carp can weigh $8 \mathrm{~kg}$ and can be up to $65 \mathrm{~cm}$ long. For carp species including the size of a large carp can even say that most big carp species. The result of egg production once spawned very much because it amounted to thousands. The criteria that have been determined on the superior sires of the Gurame Soang are $\mathrm{C} 1$ : ideal weight, $\mathrm{C} 2$ : physical defect, $\mathrm{C} 3$ : fish motion, C4: head shape, C5: body color.

\subsubsection{Ideal weight (C1)}

The ideal weight of carp for harvesting, $1.5 \mathrm{~kg}$ per tail with the age of one and a half years. For the selection of superior Gurame bloodstock, the minimum weight is $2 \mathrm{~kg}$ to $3 \mathrm{~kg}$ and the effective weight is from $2.5 \mathrm{~kg}$ to $3 \mathrm{~kg}$.

Table 1. Fish Weight Criteria

\begin{tabular}{|c|c|c|}
\hline Criteria & Criteria Parameter & Criteria Value \\
\hline \multirow{4}{*}{ Fish Weight } & $2401 \mathrm{gr}-2500 \mathrm{gr}$ & Very Less $=1$ \\
\cline { 2 - 3 } & $2501 \mathrm{gr}-2600 \mathrm{gr}$ & Less $=2$ \\
\cline { 2 - 3 } & $2601 \mathrm{gr}-2700 \mathrm{gr}$ & Enough $=3$ \\
\cline { 2 - 3 } & $2701 \mathrm{gr}-2800 \mathrm{gr}$ & Good $=4$ \\
\cline { 2 - 3 } & $>2800$ & Very good $=5$ \\
\hline
\end{tabular}

\subsubsection{Physical disability (C2)}

Note that Gurame fish can be observed from the body shape of the fish, for example, the body is injured, the stomach is not bulging and the growth of dwarf fish is not in accordance with the age of normal carp, the fish are not suitable to be superior because they can affect the marriage process. Look for fish with good body shape.
Table 2. Physical disability Criteria

\begin{tabular}{|c|l|l|}
\hline Criteria & Criteria Parameter & Criteria Value \\
\hline $\begin{array}{l}\text { Physical } \\
\text { disability }\end{array}$ & Dwarf growth & Less $=1$ \\
\cline { 2 - 3 } & Normal growth & Good $=4$ \\
\hline
\end{tabular}

\subsubsection{Fish movements (C3)}

The movement of the carp in good condition is agile. If the motion of the fish is not agile, then the fish may be sick and cannot be used in the selection of superior sires.

Table 3. Fish Movement Criteria

\begin{tabular}{|l|l|l|}
\hline Criteria & Criteria Parameter & Criteria Value \\
\hline Fish & Not Agile & Less $=1$ \\
\cline { 2 - 3 } $\begin{array}{l}\text { Movement } \\
\text { Motion }\end{array}$ & Agile & Good $=3$ \\
\cline { 2 - 3 } & Very Agile & Very good $=4$ \\
\hline
\end{tabular}

\subsubsection{Head shape (C4)}

The ideal form of Gurame Soang fish head is to have a clearly visible bulge on the head of the fish.

Table 4. Head Shape Criteria

\begin{tabular}{|l|l|l|}
\hline Criteria & Criteria Parameter & Criteria Value \\
\hline Head & Flat & Less $=1$ \\
\cline { 2 - 3 } Shape & Has a bulge & Good $=3$ \\
\hline
\end{tabular}

\subsubsection{Body Color (C5)}

The last, the body color. The color of the young Gurame Soang fish is blackish blue. The color will change when the Gurame fish is in the approaching adult phase to a yellowish brown color. The color of the fish body is ideal for being a brood, which is yellowish brown.

Table 5. Body Color Criteria

\begin{tabular}{|c|l|l|}
\hline Criteria & Criteria Parameter & Criteria Value \\
\hline Body Color & Blackish blue & Less $=1$ \\
\cline { 2 - 3 } & Yellowish-brown & Good $=3$ \\
\hline
\end{tabular}

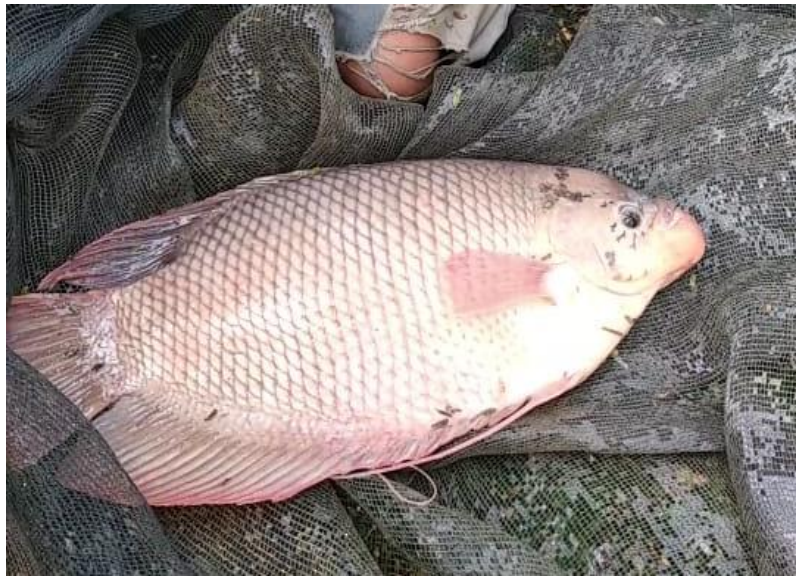

Fig. 1. Gurame Soang 


\subsection{Weighted Product (WP)}

Weighted Product (WP) is a multi-criteria decision analysis that is popular and is a method of multi criteria decision making. Like all FMADM methods, WP is a finite set of decisions described in terms of some decision criteria. Weighted product methods use multiplication to connect attributes, where the rating of each attribute should be advanced with the corresponding attribute weights. This process is similar to the process of normalization [3-4].

Weighted Products calculated based on the rate of interest. Product Weighted level of interest method, namely:

1. Very Unimportant

2. Not Important

3. Self-Important

4. Important

5. Very Important

The process of normalization criteria weight (W), $\Sigma \mathrm{W}=$ 1 is:

$$
W_{j}=\frac{W_{j}}{\Sigma W_{j}}
$$

Description: Wj: Weight attribute

$\Sigma \mathrm{Wj}$ : The sum of the weights of attributes

Preference is given to alternatives:

Information:

$$
\mathrm{Si}=\prod_{j=1}^{n} x_{i j}{ }^{w j}
$$

$\mathrm{Si}=$ Result decisions on the normalization alternative to $-\mathrm{i}$

$\mathrm{Xij}=$ Rating Alternatives per attributes

$\mathrm{Wj}=$ Weight attribute

$\mathrm{i}=$ Alternative

\section{$\mathrm{J}=$ Attributes}

$\mathrm{Nj} \Pi=\mathrm{i}$ Xij $=$ Multiplication alternative rating per attribute of $j=1-n$

In this alternative where $\Sigma \mathrm{Wj}=1$.

$\mathrm{Wj}$ is the rank of positive value to attribute profits, and negative values to attribute costs. Relative preference of each alternative $(\mathrm{V})$, provided:

$$
\mathrm{Vi}=\frac{\prod_{j=1}^{n} \boldsymbol{x}_{i j}{ }^{w j}}{\prod_{j=1}^{n}\left(\boldsymbol{x}_{j}^{w}\right)^{w j}}
$$

Information:

$\mathrm{V}_{\mathrm{i}}=$ Result alternate preference to $-\mathrm{i}$

$\mathrm{X}_{\mathrm{ij}}=$ Rating alternate per attribute

$\mathrm{W}_{\mathrm{j}}=$ Weight attribute

$\mathrm{i}=$ Alternative

$\mathrm{J}=$ Attributes

$\Pi n j=\mathrm{iX}_{\mathrm{ij}}=$ Multiplication alternative rating per attribute $\Pi n j=\mathrm{i}\left(\mathrm{X}_{\mathrm{i}}^{*}\right) \mathrm{Wh}=$ the sum of the multiplication result per attribute alternative rating.

\subsection{Simple Additive Weighting (SAW)}

Simple Additive weighting method (SAW) also known as the term is often a weighted summation method. The basic concept is to find the SAW method of rating the performance of a weighted sum of each alternative on all attributes. SAW method requires a process of normalizing the decision matrix $(\mathrm{X})$ to a scale that can be compared with all the ratings of existing alternatives. SAW method requires decision makers determining the weights for each attribute. The total score for alternatives is obtained by adding up all the multiplication of rating (which can be compared cross-attribute) and the weight of each attribute. Rating each attribute dimension must be free in the sense that has gone through the process of normalization previous matrix [3-4].

Here are the similarities that exist in the SAW method:

$$
r_{i j}=\left\{\begin{array}{cc}
\frac{x_{i j}}{\operatorname{Max} x_{i j}} & \text { Jika } j \text { adalah atribut benefit } \\
\frac{\operatorname{Min} x_{i j}}{x_{i j}} & \text { Jika } j \text { adalah lahan }(\cos t)
\end{array}\right.
$$

Information:

$r_{i j}=$ Rating normalized performance of alternatives on attribute

Max xy = max value if you are looking for is an attribute gains or highest value.

Min Min xy = value if the search is an attribute of land or lowest value.

Preference value for each alternative is given as:

$$
V_{i}=\sum_{j=1}^{n} w_{j} r_{i j}
$$

Information:

$\mathrm{A}_{\mathrm{i}}=$ Alternative

$\mathrm{C}_{\mathrm{j}}=$ Criteria

$\mathrm{W}_{\mathrm{j}}=$ Weight Preferences

$\mathrm{V}_{\mathrm{i}}=$ The preference for each alternative

$\mathrm{x}_{\mathrm{ij}}=$ Value of each criterion alternatives

Value $V_{i}$ indicates that alternative $A_{i}$ is elected. As for the criteria are divided into two categories for positive value in the criteria profits and negative value the cost criteria [3-8].

Briefly, the algorithm SAW method is:

1. Give the value of each alternative $\left(A_{i}\right)$ on each of the criteria $\left(C_{j}\right)$ that has been determined where the value obtained by crisp values; $i: 1,2, \ldots, m$ and $j=1,2, \ldots$, n.

2. Give the weight values (W) are also obtained by crisp values.

3. Normalized matrix by calculating the value of normalized performance rating $\left(\mathrm{r}_{\mathrm{ij}}\right)$ of alternative $\left(A_{i}\right)$ in attributes $\left(C_{j}\right)$ Based on equations that are tailored to the type of attributes (attributes advantage/benefit = MAXIMUM or attributes land $/$ cost $=$ MINIMUM). If the form of attribute profits then crisp values $\left(\mathrm{x}_{\mathrm{ij}}\right)$ of each column attribute divided by crisp values MAX $\left(\mathrm{MAX} \mathrm{x}_{\mathrm{ij}}\right)$ of each column, while on land attributes, crisp value MIN (MIN $\mathrm{x}_{\mathrm{ij}}$ ) of each column attribute divided by crisp values $\left(\mathrm{x}_{\mathrm{ijj}}\right)$ each column.

4. Perform the ranking process by multiplying the normalized matrix $(\mathrm{R})$ with the value of the weight (W). 
Determining the value of preference for each alternative $\left(\mathrm{V}_{\mathrm{i}}\right)$ By summing the product of the normalized matrix $(\mathrm{R})$ with the value of the weight $(\mathrm{W})$. Value $V_{i}$ Larger indicate that alternative $A_{i}$ be elected,

\section{Result and Discussion}

\subsection{Description of the System}

Selection of Gurame Soang for superior sires using Weighted Methods Product and Simple Additive Weighting method. This system resulted in a recommendation of Gurame used as superior sires Gurame species Soang for novice breeders. Users in the system or application can be used by novice breeders who do not understand how to choose the criteria of Gurame Soang for superior sires when users run the system will display the initial form. Form the beginning there is a menu bar that contained some form data selection Gurame Soang, the weights data of Gurame Soang, WP and SAW calculation. Form data contained Gurame Soang which has been inputted in advance.

The next page is the calculation of the Weighted Product form in the previous form of data weighting criteria have been changed directly calculated, after getting the results of the count normalization weighting $S$ vector, after getting results and then calculate the value of $\mathrm{V}$ vector. The final calculation is a method of SAW, The first step in the method of SAW is the normalization matrix before looking at the column max value for each criterion. After the result of normalization then perform the calculation equation, the ranking and alternative data from the SAW sum equation. The final result of the calculation method of the WP and SAW method has been obtained and produced. The output value or the final value would be the recommendation for novice breeders as determining the best recommendations Gurame Soang superior sires.

The data collected as many as 10 data with alternative data results from breeder fish totaling 10 data and the data retrieved 4 top of recommendations based on the calculation accuracy rate.

\subsection{Implementation}

Implementation is the process of making the realization of applications based on the design of the system-design has been done. This implementation resulted in an application that has multiple pages or forms that can be accessed by the user.

\subsubsection{Main page}

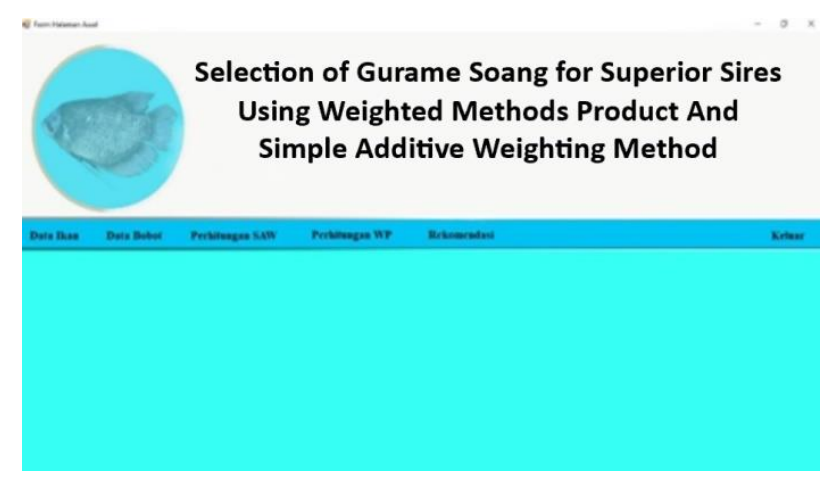

Fig. 2. Main page

Home is a second page that appears when users have successfully login. This page has seven menu that is Gurame Soang data, weighting data, WP calculations, SAW calculations, and recommendations.

\subsubsection{Gurame Soang Superior Sires}

Gurame Soang superior sires are available pages to display data of Gurame Soang. This page has a data grid view and six textbox. The info text used to know the details of the criteria of the fish, as shown in Fig.3.

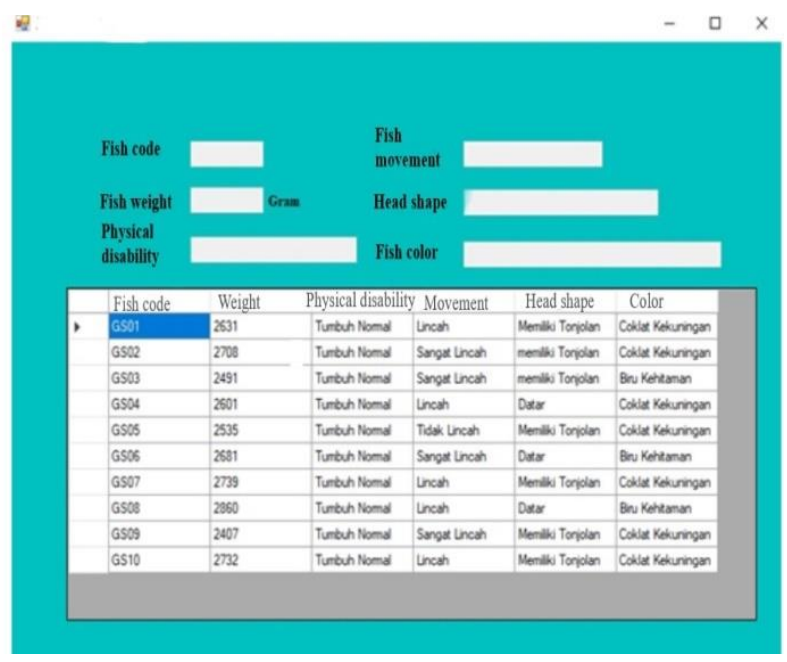

Fig. 3. Data on Featured Gurame Soang

There is no button add, change, or even remove, because the data on this form has been inputted manually to the database because the data is real, cannot be changed. Alternative number is 10 data Gurame Soang superior sires.

\subsubsection{The Weighting Data}

The weighting data page is the page to store normalization criteria weight. On this page there are two data grid view and two button process and remove. Button normalization process is used to process the data into weight value criteria, and delete to data weighting criteria. 


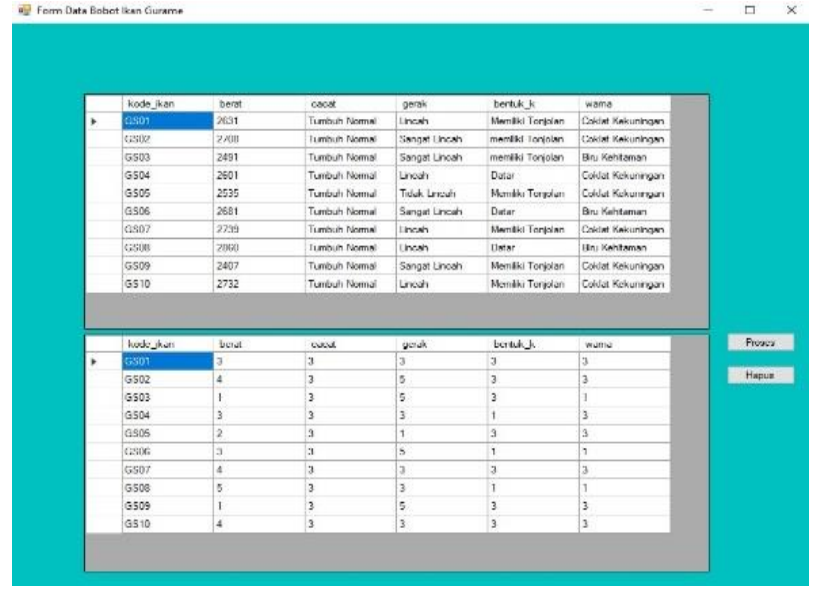

Fig. 4. The Weighting Data page

\subsubsection{WP Calculations page}

This page serves to store the results of the calculation and counting methods Weighted Product. There are two data grid view and one count button to calculate the method of Weighted Product.

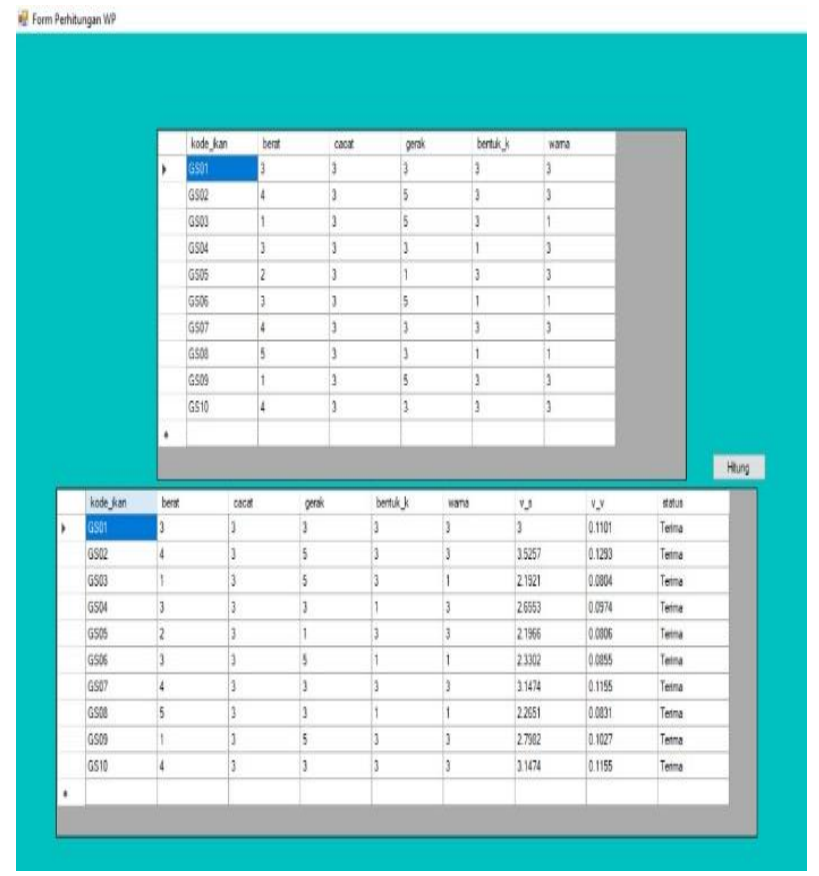

Fig. 5. WP Calculations page

\subsubsection{SAW Calculations page}

This page serves to store the results of calculations and compute Simple Additive weighting method. There are two data grid view and one count button in this page. Button arithmetic was used to calculate the method of Simple Additive weighting.

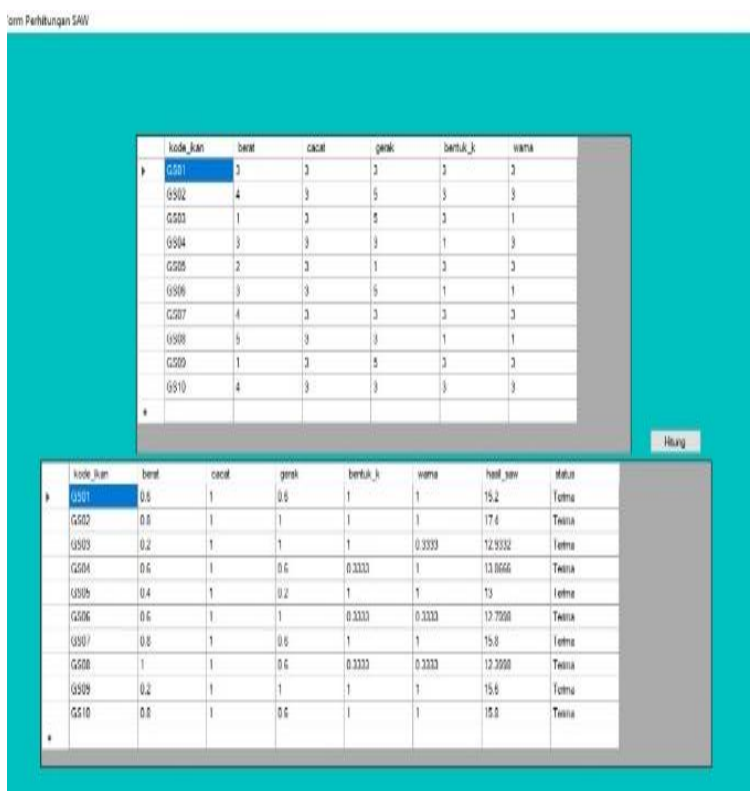

Fig.6. SAW Calculations page

\subsubsection{Recommended page}

This page is a data page of superior sires carp has been calculated and recommended as superior sires are ready. There are two data grid view and two buttons in this page for recommendations.

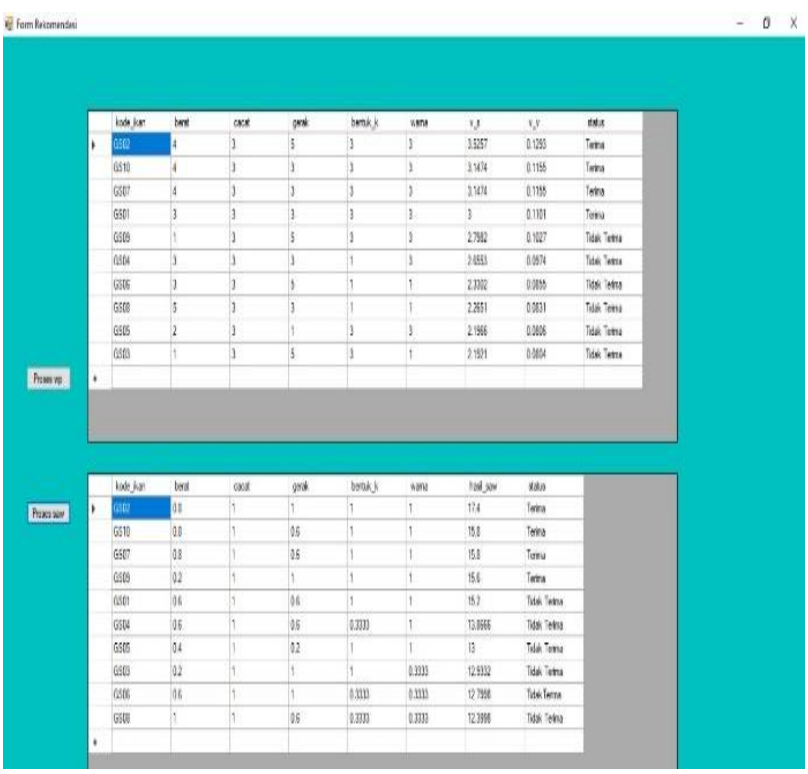

Fig. 7. Recommended page

\subsubsection{About Gurame Soang Page}

This is the Gurame Soang page that described about itself and explain any criteria for superior sires. 


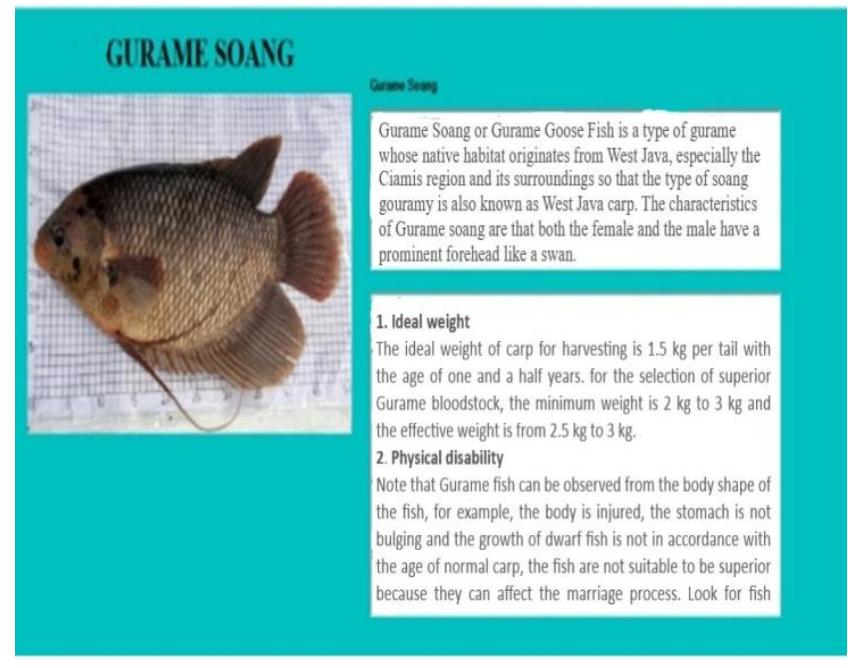

Fig. 8. About Gurame Soang Page

\subsection{Manual Calculation Testing}

The test is performed to determine an application made in accordance with the purpose. The test is done using a manual calculation. Carried out tests on ten (10) Data carp superior sires that will be superior sires to determine the outcome of carp breeding recommendations. Carp superior sires Data presented in Table 6, as for one of the conversion process in Table 7 .

Table 6. Gurame Soang Superior Sires Data

\begin{tabular}{|l|c|c|c|c|c|}
\hline $\begin{array}{l}\text { Fish } \\
\text { code }\end{array}$ & $\begin{array}{c}\text { Fish } \\
\text { weight }\end{array}$ & $\begin{array}{c}\text { Physical } \\
\text { disability }\end{array}$ & $\begin{array}{c}\text { Fish } \\
\text { movement }\end{array}$ & $\begin{array}{c}\text { Head } \\
\text { shape }\end{array}$ & Body color \\
\hline GS01 & 2531 gr & Normal & Agile & $\begin{array}{c}\text { has a } \\
\text { bulge }\end{array}$ & $\begin{array}{c}\text { Yellowish- } \\
\text { brown }\end{array}$ \\
\hline GS02 & 2708 gr & Normal & $\begin{array}{c}\text { very } \\
\text { Agile }\end{array}$ & $\begin{array}{c}\text { has a } \\
\text { bulge }\end{array}$ & $\begin{array}{c}\text { Yellowish- } \\
\text { brown }\end{array}$ \\
\hline GS03 & 2491 gr & Normal & $\begin{array}{c}\text { very } \\
\text { Agile }\end{array}$ & $\begin{array}{c}\text { has a } \\
\text { bulge }\end{array}$ & $\begin{array}{c}\text { Blackish } \\
\text { blue }\end{array}$ \\
\hline GS04 & 2501 gr & Normal & Agile & Flat & $\begin{array}{c}\text { Yellowish- } \\
\text { brown }\end{array}$ \\
\hline GS05 & 2535 gr & Normal & not Agile & $\begin{array}{c}\text { has a } \\
\text { bulge }\end{array}$ & $\begin{array}{c}\text { Yellowish- } \\
\text { brown }\end{array}$ \\
\hline GS06 & 2681 gr & Normal & $\begin{array}{c}\text { very } \\
\text { Agile }\end{array}$ & $\begin{array}{c}\text { Flat } \\
\text { Blackish } \\
\text { blue }\end{array}$ \\
\hline GS07 & 2739 gr & Normal & Agile & $\begin{array}{c}\text { has a } \\
\text { bulge }\end{array}$ & $\begin{array}{c}\text { Yellowish- } \\
\text { brown }\end{array}$ \\
\hline GS08 & 2860 gr & Normal & Agile & Flat & $\begin{array}{c}\text { Blackish } \\
\text { blue }\end{array}$ \\
\hline GS09 & 2407 gr & Normal & $\begin{array}{c}\text { very } \\
\text { Agile }\end{array}$ & $\begin{array}{c}\text { has a } \\
\text { bulge }\end{array}$ & $\begin{array}{c}\text { Yellowish- } \\
\text { brown }\end{array}$ \\
\hline GS10 & 2732 gr & Normal & Agile & $\begin{array}{c}\text { has a } \\
\text { bulge }\end{array}$ & $\begin{array}{c}\text { Yellowish- } \\
\text { brown }\end{array}$ \\
\hline
\end{tabular}

Table 7. Alternative Data Conversion Process Gurame Soang

\begin{tabular}{|l|l|l|c|}
\hline $\begin{array}{l}\text { Alterna- } \\
\text { tive }\end{array}$ & Criteria & Case & $\begin{array}{l}\text { Weight } \\
\text { conversion }\end{array}$ \\
\hline GS01 & Weight & 2631g & 3 \\
\hline GS01 & $\begin{array}{l}\text { Physical } \\
\text { disability }\end{array}$ & Normal & 3 \\
\hline GS01 & $\begin{array}{l}\text { Fish } \\
\text { movement }\end{array}$ & Agile & 3 \\
\hline
\end{tabular}

\begin{tabular}{|l|l|l|c|}
\hline GS01 & Head shape & has a bulge & 3 \\
\hline GS01 & Color & Yellowish-brown & 3 \\
\hline
\end{tabular}

Based on conversion of data values Superior Brood stock Gurame Soang, then obtained the value of each alternative criteria.

Table 8. Results Values Criteria

\begin{tabular}{|c|c|c|c|c|c|c|}
\hline No & $\begin{array}{c}\text { Fish } \\
\text { code }\end{array}$ & $\begin{array}{c}\text { Fish } \\
\text { Weight }\end{array}$ & $\begin{array}{c}\text { Physical } \\
\text { disability }\end{array}$ & $\begin{array}{c}\text { Fish } \\
\text { Movement }\end{array}$ & $\begin{array}{c}\text { Head } \\
\text { shape }\end{array}$ & $\begin{array}{c}\text { Fish } \\
\text { Color }\end{array}$ \\
\hline 1 & GS01 & 3 & 3 & 3 & 3 & 3 \\
\hline 2 & GS02 & 4 & 3 & 5 & 3 & 3 \\
\hline 3 & GS03 & 1 & 3 & 5 & 3 & 1 \\
\hline 4 & GS04 & 3 & 3 & 3 & 1 & 3 \\
\hline 5 & GS05 & 2 & 3 & 1 & 3 & 3 \\
\hline 6 & GS06 & 3 & 3 & 5 & 1 & 1 \\
\hline 7 & GS07 & 4 & 3 & 3 & 3 & 3 \\
\hline 8 & GS08 & 5 & 3 & 3 & 1 & 1 \\
\hline 9 & GS09 & 1 & 3 & 5 & 3 & 3 \\
\hline 10 & GS10 & 4 & 3 & 3 & 3 & 3 \\
\hline
\end{tabular}

Has obtained a decision matrix of Table 8 are:

Decision Matriks $=\left[\begin{array}{lllll}3 & 3 & 3 & 3 & 3 \\ 4 & 3 & 5 & 3 & 3 \\ 1 & 3 & 5 & 3 & 1 \\ 3 & 3 & 3 & 1 & 3 \\ 2 & 3 & 1 & 3 & 3 \\ 3 & 3 & 5 & 1 & 1 \\ 4 & 3 & 3 & 3 & 3 \\ 5 & 3 & 3 & 1 & 1 \\ 1 & 3 & 5 & 3 & 3 \\ 4 & 3 & 3 & 3 & 3\end{array}\right]$

\subsubsection{WP Calculation Manual}

WP method in the first step that must be done after making the decision matrix was to make weight beforehand. Existing criteria weights normalized by calculating the amount of weight divided by the total number of weights. The process of normalization of weight calculation by equation (1).

$$
\begin{aligned}
& \mathrm{W} 1=\frac{\mathrm{a}}{\text { jumlah keseluruhan bobot }}=\frac{\mathrm{a}}{18}=0,1667 \\
& \mathrm{~W} 2=\frac{5}{\text { jumlahkeseluruhan bobot }}=\frac{5}{18}=0,2778 \\
& \mathrm{~W} 3=\frac{4}{\text { jumlah keseluruhan bobot }}=\frac{4}{18}=0,2222 \\
& \mathrm{~W} 4=\frac{2}{\text { jumlah keseluruhan bob ot }}=\frac{2}{18}=0,1111 \\
& \mathrm{~W} 5=\frac{2}{\text { jumlah keseluruhan bobot }}=\frac{4}{18}=0,2222
\end{aligned}
$$

The results of the criteria weights normalization calculation, calculated the value of vector $\mathrm{W}$ that was obtained from the sum of the normalized matrix multiplication element row with a preference weighting (W) corresponding column of the matrix. Calculation of the vector $\mathrm{W}$ at each weight of preference on any symptoms that would be a reference in the calculation of normalized vector calculation $\mathrm{S}$. normalization vector $\mathrm{S}$ is calculated based on the equation (2). Here one vector calculation $\mathrm{S}$ multiplying matrices decisions that have been raised to the value of improvements weights: 


$$
\begin{aligned}
\mathrm{S} 1 & =() \times() \times() \times() \times() 3^{0,1667} 3^{0,2778} 3^{0,22222} 3^{0,1111} 3^{0,2222} \\
& =3
\end{aligned}
$$

The above calculation obtained calculation results as shown in Table 9.

Table 9. Vector S Calculation Results

\begin{tabular}{|l|l|}
\hline Alternative & Value Vector S \\
\hline S1 & 3,0000 \\
\hline S2 & 3.5257 \\
\hline S3 & 2.1922 \\
\hline S4 & 2.6553 \\
\hline S5 & 2.1966 \\
\hline S6 & 2.3301 \\
\hline S7 & 3.1473 \\
\hline S8 & 2.2649 \\
\hline S9 & 2.7983 \\
\hline S10 & 3.1473 \\
\hline
\end{tabular}

The results of the calculation of the vector $S$, the next will be added together and the result used as dividers on each alternative. The calculation of normalized vector $\mathrm{V}$ is calculated based on the equation (3).Here's one vector calculation $\mathrm{V}$ which add up all the results of the vector $\mathrm{S}$ to be used as a divider for each alternative:

$$
\begin{aligned}
& \mathrm{V} 1=\frac{3,0000}{\frac{3,0000+2,5257+2,1922+2,6553+2,1966}{+2,3301+2,1473+2,2649+2,7983+3,1473}} \\
& =\frac{3,0000}{27,2579} \\
& =0.1101
\end{aligned}
$$

The above calculation results obtained vector value $\mathrm{V}$ as shown in Table 10.

Table 10. Vector V Calculation Results

\begin{tabular}{|c|c|}
\hline Alternative & Value Vector V \\
\hline V1 & .1101 \\
\hline V2 & .1293 \\
\hline V3 & .0804 \\
\hline V4 & .0974 \\
\hline V5 & .0806 \\
\hline V6 & .0855 \\
\hline V7 & .1155 \\
\hline V8 & .0831 \\
\hline V9 & .1027 \\
\hline V10 & .1155 \\
\hline
\end{tabular}

\subsubsection{SAW Calculation Manual}

Matrix decisions that have been obtained from Table. 8 that had previously been done manually calculation methods WP, having obtained further manual calculation WP manual calculation SAW.SAW method in the first step is done after making the decision matrix is to normalize the matrix. The matrix above is a normalization matrix where each column divided by the greatest number.

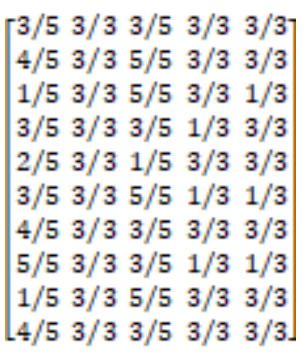

Fig. 10. Normalization Matrix SAW

$\left\{\begin{array}{ccccc}0,6 & 1 & 0,6 & 1 & 1 \\ 0,8 & 1 & 1 & 1 & 1 \\ 0,2 & 1 & 1 & 1 & 0,3333 \\ 0,6 & 1 & 0,6 & 0,3333 & 1 \\ 0,4 & 1 & 0,2 & 1 & 1 \\ 0,6 & 1 & 1 & 0,3333 & 0,3333 \\ 0,8 & 1 & 0,6 & 1 & 1 \\ 1 & 1 & 0,6 & 0,3333 & 0,3333 \\ 0,2 & 1 & 1 & 1 & 1 \\ 0,8 & 1 & 0,6 & 1 & 1\end{array}\right\}$

Fig. 11. Normalized Matrix SAW

In Fig. 11, the first column of the first row numbers means 3 divided by 5 the result is 0.6 , the first column of the second row of numbers means 3 divided by 3 result 1 as well as the column and the next line. Results of the calculations further normalization matrix is multiplied by the weighting of each criterion.

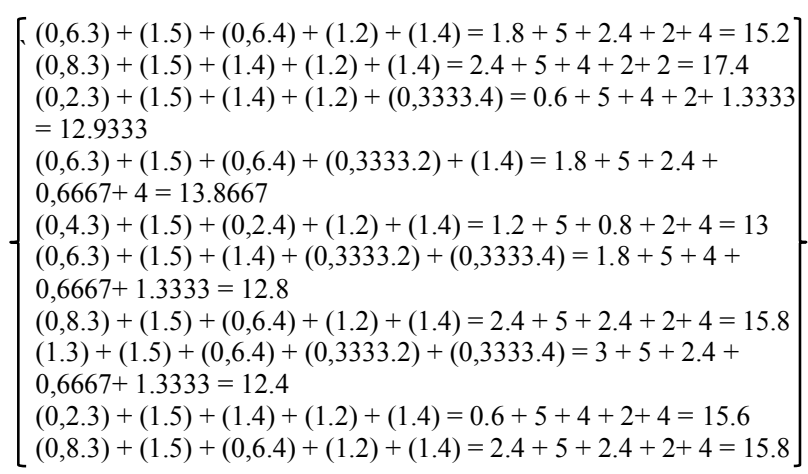

Matrix multiplication with the respective weighting criteria then added together yield per row so we get results that make reference to the recommendation of Gurame Soang superior sires.

Table 11. The SAW calculation result

\begin{tabular}{|c|c|}
\hline Alternative & Value \\
\hline V1 & 15.2 \\
\hline V2 & 17.4 \\
\hline V3 & 12.9333 \\
\hline V4 & 13.8667 \\
\hline V5 & 13 \\
\hline V6 & 12.8 \\
\hline V7 & 15.8 \\
\hline V8 & 12.4 \\
\hline V9 & 15.6 \\
\hline V10 & 15.8 \\
\hline
\end{tabular}




\subsection{Manual Testing Results and System Results}

The test is performed to determine whether the system is built is correct as required. Data were examined totaled 10 data sires Superior Gurame Soang. The results of the decision support system matched with the manual and the results can be seen in Table 12 and Table 13.

Table 12. Calculation Manual with WP System

\begin{tabular}{|l|l|l|l|c|}
\hline No. & Name & $\begin{array}{l}\text { System } \\
\text { Value }\end{array}$ & $\begin{array}{l}\text { Manual } \\
\text { Value }\end{array}$ & Info. \\
\hline 1 & GS01 & 0.1101 & 0.1101 & fit \\
\hline 2 & GS02 & 0.1293 & 0.1293 & fit \\
\hline 3 & GS03 & 0.0804 & 0.0804 & fit \\
\hline 4 & GS04 & 0.0974 & 0.0974 & fit \\
\hline 5 & GS05 & 0.0806 & 0.0806 & fit \\
\hline 6 & GS06 & 0.0855 & 0.0855 & fit \\
\hline 7 & GS07 & 0.1155 & 0.1155 & fit \\
\hline 8 & GS08 & 0.0831 & 0.0831 & fit \\
\hline 9 & GS09 & 0.1027 & 0.1027 & fit \\
\hline 10 & GS10 & 0.1155 & 0.1155 & fit \\
\hline
\end{tabular}

Table 13. Calculation Manual with SAW System

\begin{tabular}{|l|l|l|l|c|}
\hline No & Name & System Value & Manual Value & Infor. \\
\hline 1 & GS01 & 15.2 & 15.2 & fit \\
\hline 2 & GS02 & 17.4 & 17.4 & fit \\
\hline 3 & GS03 & 12.93333333 & 12.93333333 & fit \\
\hline 4 & GS04 & 13.86666667 & 13.86666667 & fit \\
\hline 5 & GS05 & 13 & 13 & fit \\
\hline 6 & GS06 & 12.8 & 12.8 & fit \\
\hline 7 & GS07 & 15.8 & 15.8 & fit \\
\hline 8 & GS08 & 12.4 & 12.4 & fit \\
\hline 9 & GS09 & 15.6 & 15.6 & fit \\
\hline 10 & GS10 & 15.8 & 15.8 & fit \\
\hline
\end{tabular}

\subsection{Testing The Accuracy Level}

Tests were performed on a system with 10 data calculation alternatively, obtained 4 on the highest value of fish that will be superior sires Soang Gurame fish. Calculation results of the ranking system method will be compared to 10 Gurame Soang data results from fish farmers, there are 4 data was selected. The accuracy of the system recommendation was compared to the fish farmers' data, then we got the accuracy of the two methods. Compatibility of data results from breeders with WP and SAW system can be seen in Table 13 and Table 14.

Table 14. Results Breeders Data, WP and SAW Methods

\begin{tabular}{|l|l|l|}
\hline Fish code & WP result & SAW result \\
\hline GS02 & GS02 & GS04 \\
\hline GS10 & GS07 & GS03 \\
\hline GS07 & GS10 & GS07 \\
\hline GS01 & GS01 & GS10 \\
\hline GS09 & GS09 & GS02 \\
\hline GS04 & GS04 & GS09 \\
\hline GS06 & GS06 & GS06 \\
\hline
\end{tabular}

\begin{tabular}{|l|l|l|}
\hline Fish code & WP result & SAW result \\
\hline GS08 & GS08 & GS01 \\
\hline GS05 & GS05 & GS08 \\
\hline GS03 & GS03 & GS05 \\
\hline
\end{tabular}

Table 15. Results alternative breeders and WP system

\begin{tabular}{|l|l|l|l|l|}
\hline No. & Fish code & $\begin{array}{l}\text { Results } \\
\text { breeder }\end{array}$ & $\begin{array}{l}\text { WP Test } \\
\text { Results }\end{array}$ & $\begin{array}{l}\text { Test } \\
\text { result }\end{array}$ \\
\hline 1 & GS02 & T & T & fit \\
\hline 2 & GS10 & T & T & fit \\
\hline 3 & GS07 & T & T & fit \\
\hline 4 & GS01 & T & TD & Not fit \\
\hline 5 & GS09 & TD & TD & fit \\
\hline 6 & GS04 & TD & T & Not fit \\
\hline 7 & GS06 & TD & TD & fit \\
\hline 8 & GS08 & TD & TD & fit \\
\hline 9 & GS05 & TD & TD & fit \\
\hline 10 & GS03 & TD & TD & fit \\
\hline & & accuracy & & $80 \%$ \\
\hline
\end{tabular}

Table 15 shows the 10 alternative data Gurame Soang. There are 2 data is not fit with the data results breeders. Alternatives are fit with the data results of the breeder as much as 8 data, so the accuracy of the data in the table is $80 \%$. Test table of data, $\mathrm{T}=$ Accepted and $\mathrm{TD}=$ Not Accepted.

$$
\frac{\mathrm{g}}{10} \times 100 \%=80 \%
$$

Table 16. Results alternative breeders and SAW system

\begin{tabular}{|l|l|l|l|l|}
\hline No. & $\begin{array}{l}\text { Fish } \\
\text { code }\end{array}$ & $\begin{array}{l}\text { Results } \\
\text { breeder }\end{array}$ & $\begin{array}{l}\text { SAW Test } \\
\text { Results }\end{array}$ & $\begin{array}{l}\text { Test } \\
\text { result }\end{array}$ \\
\hline 1 & GS02 & T & T & Fit \\
\hline 2 & GS10 & T & TD & Not fit \\
\hline 3 & GS07 & T & T & Fit \\
\hline 4 & GS01 & T & TD & Not fit \\
\hline 5 & GS09 & TD & TD & Fit \\
\hline 6 & GS04 & TD & T & Not fit \\
\hline 7 & GS06 & TD & TD & Fit \\
\hline 8 & GS08 & TD & TD & Fit \\
\hline 9 & GS05 & TD & TD & Fit \\
\hline 10 & GS03 & TD & T & Not fit \\
\hline & accuracy & \multicolumn{2}{|l}{} & $60 \%$ \\
\hline
\end{tabular}

Table 16 shows that the 10 alternative data Gurame Soang. There are 4 data are not fit with the data results breeders. Alternatives are in accordance with the data results of the breeder as much as 6 data, so the accuracy of the data in the table is $60 \%$. In the test table of data, T $=$ Accepted and TD $=$ Not Accepted.

$$
\frac{6}{10} \times 100 \%=60 \%
$$

The level of accuracy obtained from the two methods are different, the accuracy rate of $80 \%$ WP method and SAW method for an accuracy rate of $60 \%$. The method is suitable in cases of superior sires election is a method of Gurame Soang WP with an accuracy of $80 \%$

\section{Conclusion}

The results of the study it can be concluded that the decision support system for selecting Gurami Soang 
sires using the WP and SAW method was successfully created. From the 10 alternative data of Gurame Soang sires obtained the results of testing using the Weighted Product method get an $80 \%$ accuracy value and Simple Additive weighting gets an accuracy value of $60 \%$. The results showed that the accuracy of the two methods was obtained by the 4 best Gurame Soan broods.

\section{References}

1. K. Mahyuddin, Sower Self Reliance Jakarta (2013)

2. Azrita, H. Syandri, International Journal of Fisheries and Aquatic Studies 2 (6), 344-350 (2015)

3. Ramadiani, et.al. The 2nd ICENIS, Semarang, E3S Web Conf., 3110002 (2018)

4. N. Nurjannah, Journal of Information Mulawarman. 10 (2), 2-6 (2015)

5. Ramadiani, N. Aini, et.al. Proc. EECSI Yogyakarta, Indonesia, 133 -139 (2017)

6. R. Ramadiani, A. Rahma, Register: Jurnal Ilmiah Teknologi Sistem Informasi 5 (1), 1-12 (2019)

7. Ramadiani, R. Kurniawan, International Journal of Engineering, Information Science and Applied Sciences (IJEIS-AS) 1(1) (2018)

8. Ramadiani, et.al. Jurnal Teknologi Informasi dan Ilmu Komputer (JTIIK) 6 (2), 155-162 (2019) 